\title{
Remembrance between Act and Event: Anne Enright's The Gathering
}

Jean-Michel Ganteau

Univ Paul Valéry Montpellier 3, EMMA EA741, F34000, Montpellier, France

In an article considering the ubiquity of trauma in the contemporary Irish novel, Constanza del Rio Alvaro reminds her reader of most of the ingredients of trauma fiction. She surveys both the thematic characteristics of this type of production (violence, uncertainty, catastrophe and crises affecting collective identity) and its formal traits - among which fragmentation, discontinuity and, last but not least, the temporal dislocation inherent in the powers of Nachträglichkeit (5-6). In so doing, she pays special attention to collective trauma, even while focusing on more individual instances, and comes up with the following suggestion: "the solution for such a permanent threat to collective identity may not lie so much in forgetfulness as in re-memory, to use the term coined by Toni Morrison in her novel Beloved (1987)" (5). The "radical dysfunction of memory" (6) that trauma brings about may be possibly healed or at least dealt with by converting traumatic memory into narrative memory, which is a way to "bring the past to memory as a way to exorcise the ghosts of the past" (7).

As demonstrated by many commentators, contemporary Ireland provides many instances of collective and individual trauma. This is underlined by del Rio Alvaro herself as she lists a series of national catastrophes that, over the last two decades, have hit the headlines and have revealed the Celtic Tiger's silver lining: domestic violence, business and political corruption, and obviously child abuse (8). Such a state of affairs is confirmed by Carol Dell'Amico who, concentrating on Enright's Booker Prize winning The Gathering, avers that one of the novel's main functions is to bear witness to sundry types of national lapses, from neo-liberal excesses (68) to the "dour extremities of Irish Catholicism" (66) that were the hallmark of post-independence Ireland and came to be exposed fairly recently. Enright's 
novel clearly digs into the depths of collective trauma and takes part in the general process of unearthing the hidden, and of voicing what was silenced for many years. And as a matter of course, the fact that it should explicitly make the consequences of child abuse its main theme does ring with the paedophilia scandals that have come to be associated with the Catholic Church in general and the Irish Catholic Church and hierarchy in particular. This type of national trauma is documented by Enright's novel, together with the plight of some Irish women (one may think of the infamous Magdalen laundries but also of the more ordinary type of domestic violence to which some of the narrative is devoted) or handicapped children and adults (as emblematised by the figure of Uncle Brendan). The Gathering is acutely conscious of the political and the collective, even while recounting the story of an individual's relation to her dead brother, her family, and her country over the greater part of the twentieth century (from 1925 to the 1990s). Nowhere is this more pithily expressed as in one of the narrator's diatribes: "This is what shame does. This is the anatomy and mechanism of a family-a whole fucking country-drowning in shame." (168; see also 173). Seen in this light, The Gathering is some state-of-the-nation novel, and it has been apprehended as such by several commentators. ${ }^{1}$ Yet, it is also, unmistakably, a highly detailed, impressive evocation of individual trauma that allows for the description of other, related (and relating) traumas.

I would like to claim that in The Gathering the exploration of related, individual traumas is predicated on the ethical impulse consisting in meeting the others' traumas and that such an exploration systematically calls for re-memory, in del Rio Alvaro's terms. And my contention is that what Enright's novel presents us with is the paradoxes of remembrance or, more precisely, the paradoxes of the acts of remembrance that are central in the exploration of trauma. By this I mean that in The Gathering collective and individual history "can only be

\footnotetext{
${ }^{1}$ I am not using the phrase in its traditional English acceptation, the English state-of-the-nation novel being the descendent of the Victorian 'condition-of-England' novel (to take up the phrase invented by Carlyle in Past and Present), also known as industrial novel? What I have in mind here is the fact that the narratives lends itself to a fairly comprehensive radioscopy of the nation surveying its economic, social, political and cultural state. From this point of view, the state-of-the-nation novel provides a fictional testimony of the nation's evolution.
} 
grasped in the inaccessibility of its occurrence" (Caruth 1995, 8). The paradox of remembrance, which is both necessary and impossible, together with the paradox of the acts of remembrance — as re-membering or "re-memorying" more often than not implies a failure of agency-radiate from the heart of the narrative. In the following pages, I focus on The Gathering as testimony, by successively addressing the following points: impossible and contradictory remembrances, fictionalisation or inventing the past, remembrance as event.

\section{Impossible remembrances}

As indicated by Gardam, The Gathering's first-person narrator, Veronica Hegarty, evinces all the symptoms of PTSD (3). On learning about the death of her elder, favourite brother Liam, who apparently committed suicide by stepping into the waters of the Channel, on Brighton beach, wearing Wellington boots, with stones in his pockets, she won't sleep, won't let her husband get close to her, spends her nights feverishly writing and rewriting her testimony of her brother's and her family's lives, drinks and suffers what might be called hallucinations. Such a disrupted, fragmented hold on the present may well correspond to what Caruth analyses as the enduring power of PTSD, i.e. "being possessed by the past" $(1996,151)$. However, while the present seems to have dramatically dwindled in size the better to leave room for the past, in a bout of what could be considered melancholic mourning, such presence of the past is made both overwhelming and, paradoxically, inaccessible, as both narrator and reader are presented with an unmistakable case of "dysfunction of memory" (del Rio Alvaro 6) making any act of remembrance at best tentative and, in most cases, abortive. From the beginning, acts of remembrance, even while they are permanent and seem to colonise both narrative and narrator, are doomed to failure and both narrator and reader must submit to the tyranny of remembrance as event, i.e., something that affects the subject without her/his being granted any great degree of agency. 
The narrative foregrounds the relentless need for anamnesis by multiplying references to the act of remembrance. Still, strikingly, such references are almost systematically couched in negative terms: "Some days I don't remember my mother." (3); "I would love to remember how he died-" (59); "All I remember is the aftermath [. . .]" (60), etc., ad libitum. In other words, what the confessional narrative harps on is a story of impossibility, in which the fragment of a memory leads to more gaps and holes, building up the impression of a memory in rags and tatters, making remembrance always already ruinous. The text builds up some memory map that looks more like an archipelago than a peninsula or continent. In The Gathering, remembrance is relentless while memory is forever evasive, as if to confirm Françoise Davoine and Jean-Max Gaudillière's striking image of trauma as apprehended through the paradox of "thoughts without a thinker" (157). As far as textual dynamics are concerned, such structural stammering leads to the building up of a series of embedded enigmas that make the narrative even more compelling and solicit the reader's attention, responsiveness and responsibility: was Liam really sexually abused as a child and in what circumstances, why was he sent to prison as a teenager (163-70), was the narrator herself sexually abused $(134,221-24)$, were her mother and uncle abused before that time (252), was her grandmother Ada, with whom she and Liam spent a summer when the sexual aggression supposedly took place, aware of what was happening and was she an accomplice, pimping the child to Lambert Nugent, the owner of her house $(223,234)$, and eventually did the latter have an incestuous relationship with his teenage sister who was dying from tuberculosis $(45,215)$ ? As suggested above, I take the multiplication of enigmas as an ethical device, meant to make the reader empathically share in the process of memory retrieval and mapping, and getting the reader to care for the situation that is evoked throughout those pages at the individual, communal and national levels. With Enright, fiction lends its engaging powers to testimony, 
making the literary essential in the expression of witnessing and possibly putting into practice Whitehead's definition of testimony as "speaking beyond understanding" (7).

And indeed, the further away in the past the moment to be retrieved, the more distorted the memory (Laub 64) and the more difficult, tentative the act of remembrance itself, so much so that irretrievability or difficult access may edge towards contradiction and the impossibility to sort things out. It is precisely such an impossibility that makes it urgent for the narrator to embark on her quest towards testimony, as stated towards the end of the narrative: "I owe it to Liam to make things clear-what happened and what did not happen in Broadstone [their grandmother's house]." (223), in words that strikingly echo the very beginning of the incipit: "I would like to write down what happened in my grandmother's house the summer I was eight or nine, but I am not sure if it really did happen. I need to bear witness to an uncertain event." (1).

Now, in the wake of tentativeness, stammering and contradiction, uncertainty spreads through the novel and infects the confessional narrative and its reception. Not only the narrator is conscious of gaps in her remembrance but she is also aware that some of the gaps that she attempts to fill belong in the wrong place. Such a knowledge of memory's treacherous lapses as replacements appears early in the narrative, turning Veronica Hegarty into a specific instance of an unreliable narrator and tipping the scales of her unreliability towards frailty and vulnerability. This is noticeable when she realises that her memories are not necessarily her own, but the family's, or her younger sister's: “Of course I was jealous of my little sister, but I had a peculiar, fierce love for her too. It is not surprising that I steal her memories for my own." (99). One step further, the closer she gets to the scene of incest thatat least to her conscious mind-corresponds to the original offence that sent Liam on his slithering path to death, the more she becomes aware that she is the prey of false or screen memories that resolutely cast doubt on any possible access to any stabilised truth. In one of 
the climactic passages in which she evokes how, as a little girl, she caught Liam masturbating Lambert Nugent, she captures the scene with a wealth of details. The perspective of the adult narrator absents itself throughout the evocation, as the older Veronica impersonalises herself, and the reader is left with the point of view of the eight year old that she used to be. The effect is one of implacable dramatic irony, as we are told about "the boy's bare forearm, that made a bridge of flesh between himself and Mr Nugent" (144). The bridge metaphor ironically wrecks any possibility of real connection and ethical encounter, capturing the incomprehensibility of the event. Likewise, the naming of the offender ("Mr Nugent" as opposed to "Lamb Nugent," the latter being preferred throughout by the adult narrator) makes the child's voice merge with her point of view. In conformity with the rule according to which the longer untold, the more distorted an event (Laub 64), Veronica soon falters in her remembrance and the adult narrator surfaces to explicitly comment on the irretrievability of an event that she seems to be barred access to: "I think it may be a false memory, because there is a terrible tangle of things that I have to fight through to go to it. And because it is unbearable" (144). Irretrievability and consciousness of irretrievability converge in those lines as in other passages to make it clear that the truth is in the act of remembrance, not in the memory itself. Once again, the reader is presented with the paradox of the omnipresence of a past that is repeated in the present but which remains at least partly inaccessible (Freud 18, Janet 22). This confirms Anne Whitehead's liminal comment on the paradoxical, even contradictory nature of trauma fiction: "if trauma comprises an event or experience which overwhelms the individual and resists language or representation, how can it then be narrativised in fiction?" (3) It is precisely this conundrum that The Gathering as precarious testimony addresses.

As with most traumatic cases, the act of remembrance has to be content with being just that, i.e., an act, which may remain intransitive or, at least, tentative and forever inchoate. 
Such a sense of incompletion ties in nicely with the definition of testimony provided by many contemporary observers, among whom Felman who defines it as the moment when accuracy is in doubt (17). It also illustrates beautifully Laub's conception of witnessing as ceaseless struggle (61-63), which is tantamount to considering testimony not as result but as process. The Gathering, as most trauma narratives concerned with producing fictional testimony, is characterised by some double vulnerability: the vulnerability of the characters all caught in the vice of a terrible social, economic, historical and, more generally, cultural situation that manufactures victims out of the frailest individuals; and the vulnerability of a confessional form that replaces assertion with questioning, narrative or descriptive chunks with fragments, accusations with excuses or amends. The re-memorying falls short of re-membering and has to be content with mere recall. In Enright's novel, testimony is envisioned as some negative capability — though a peculiarly restless one: that of accepting failure and coming to terms with helplessness (Philips 88-117), which makes The Gathering first and foremost a vulnerable text.

\section{Inventing the past}

The Gathering is a piece of fictional testimony which pushes testimony to the extreme. As underlined above, this is done by harping on the liminality of testimony and its ruinous, fragmented state. In other words, what Veronica's ceaseless acts of remembrance flaunt is less historical content than the holes between the fugitive elements that can be retrieved. Acts of memory in Enright's novel are more often than not expressed in terms of beating about the bush or, rather, beating around the central hole of traumatic memory (Janet 11) that is ceaselessly elusive and has been defined as "internal foreign body" by Jacques Press (69). When absence, contradiction and false memories become rife, what the witness is left with is invention. And this is precisely what I think contributes to the narrative's originality: it is an 
instance of a fictional testimony that thematises the powers of fiction, as if to remind us that the experience of trauma must "also be written in a language that is always somewhat literary: a language that defies, as it claims, our understanding." (Caruth 1996, 5). The blatant fictionality of Veronica's testimony has been commented on by various critics, and it is true that a great part of Veronica's painstaking reconstruction of the past is purely imaginary.

Granted, some of the facts that she could not herself witness, like the meeting of her grandmother with both Lambert Nugent and her husband, years before her own mother was born, might have been writ large in the family annals and might be part of some handed down family myth. If this were the case, her acts of remembrance would belong to the regime of post-memory which, Hirsch reminds us, "is not identical to memory: it is 'post' but at the same time, it approximates memory in its affective force" (109). Yet, prudence is necessary when using such a concept, which was honed out in relation to the second generation of Shoah survivors, the representatives of the first generation having gone through the extreme violence of traumatic effraction. In The Gathering, even if the affective force of what is presented as memories of the narrator's pre-history is undeniable, the trio of participants in that period is never explicitly the victim of violent circumstances and the evocation of their courtship seems to exist in a time capsule of its own bearing little relation to the political and economic circumstances of the 1920s. In fact, instead of the inter-generational transmission of memory, what is at work in the novel is the invention of memory and the creation of the past, perhaps the biggest paradox affecting the acts of remembrance that the novel keeps rehearsing.

Chapter 3 is the first one to plunge into the pre-historical origins and nature of the offence: "The seeds of my brother's death were sown many years ago." (13). As the narrator has no direct access to this time line, before herself and her brother were born, a time that hosted happenings whose protagonists have been long dead, she sets herself the task of 
narrating it with the means at her disposal which, as indicated by the word "tale," are the means of fiction: "this is the tale that I would love to write: history is such a romantic place, with its jarveys and urchins and side-buttoned boots. If it would just stay still, I think, and settle down." (13). As with post-memory, the role of photographic material is essential in the transmission of a fragment from the past, and this is suggested through the strong visual solicitation of the "jarveys," "urchins" and "side buttoned boots." But with a difference, once again: those visual flashes act more as documents of a period helping contextualise an imagined episode than a transmitted memory. Such a declaration is but a prelude to the narrator's metafictional description of her own task, which is one of imaginative creation: "He must be reassembled; click clack; his muscles hooked to bone and wrapped with fat, the whole skinned over and dressed in a suit of navy or brown [. . .]" (14). Very discreetly, the narrative has moved to the present tense, replacing the act of remembrance with the content of the remembrance, coaxing back the scene into existence, or rather coaxing it into existence, as a scene that never existed but might have taken place. In other words, fictionalisation is envisaged here as a practice for interpretation.

Such narrative orientation may account for the recurrence of scenes abruptly starting with the phrase "Here is" (the first words of chapter 5 [30]), or in similar fashion ("There is" being a recurrent variation). Interestingly, they present the reader with memory capsules, often disconnected from any immediate context referring to an act of remembrance, as if they were floating to the surface of the narrator's consciousness of their own accord, which is an illusion as the effort of remembrance invades the whole of the narrative, as indicated above. The absence of any single stable memory concerning this period is thus compensated for by the impression of a very precise moment evoked in the present tense, thrown under the reader's eye through the designating, soliciting power of "here is," as if visual illusion were a guarantee of accuracy and reliability. Strikingly, the same technique is used to evoke episodes 
that the narrator herself witnessed — or at least thinks she witnessed —or else that took place when she was around and that concern a period of her life when she and her brother were staying at their grandmother's place on the fateful summer when Liam was supposedly abused. In other words, the very memories that are made up seem to be, precisely, those that are best remembered, and most faithful to reality, as indicated in the following statement: "The only things I am sure of are the things I never saw-my little blasphemies-Ada and Charlie in their marriage bed, her pubis like the breast of an underfed chicken under his large hand [ . . .]" (66-67).

Strikingly, then, occurrences that took place in the grandparents' youth and episodes that Veronica could be involved in are introduced in the same way, and made present to the reader with the same means. Such grammatical levelling tends to blur any distinction between episodes, i.e., the explicitly fictionalised ones and the supposedly faithful ones. The implication is that it becomes difficult to discriminate between the two levels of testimony and that the fictional and invented seems to contaminate the apparently witnessed, which was anyway already compounded of contradiction and impossibility. For in fact, even if half-way through the novel the narrator decides to do away with fictionalisation and what she calls "romance"-i.e., an extremely fictional type of fiction-, her repeal seems to remain provisional. The turning point in her confession, which expresses the need to regulate her act of remembrance, is couched in unambiguous terms:

I know, as I write about these things: the jacket, the stones, and my brother's nakedness underneath his clothes, that they require me to deal in facts. It is time to put an end to the shifting stories and the waking dreams. It is time to call an end to romance and just say what happened in Ada's house, the year that I was eight and Liam was barely nine. (142) 
My point is that despite this seemingly unambiguous repeal, and even if part of her testimony is identified as "tale" or "romance," the lingering power of fiction comes to contaminate all elements in the narrative and, above all, proves to be no less reliable than memory till the end of a novel. This is nowhere clearer than in an ambiguously epiphanic passage taking place in one of the final chapters when the narrator, reaching the end of her self-imposed testimony, spells out what she knows and what she does not, in a passage where negative epiphany weighs as heavily as revelation: "These are the things I do actually know. [...] These are the things I don't know [...]" (224), the unknown occupying more textual space and weighing more heavily on the narrative than the known. The Gathering presents us with a case of liminal fictional testimony where, in Caruth's terms, literary language makes us aware of the indirect referentiality of history and of the past (Caruth 1996, 18). Another way to capture this idea would be to underline the hesitation between the iconic and the indexical in Veronica Hegaty's narrative. What I mean is that the onomastics refer back to a namesake, Veronica, the woman that is supposed to have swept Christ's face on his way to Calvary, getting his features imprinted on the piece of cloth. In the case of the biblical story, the imprint as indexical sign constitutes a proof — as with photography — that the printed features - hence the represented subject — was there, as opposed to a drawing, painting or engraving of the face which would not attest to a former presence but only to an analogy between the original and the represented face. Now, I would argue that the mode of testimony that obtains in The Gathering is one in which the iconical stakes its claims to the indexical, a form in which the witness has to be content, somehow, with resemblance and similarity as no proof-giving index is available. This simultaneously points towards the necessary vulnerability of this testimony - and, possibly, of most testimonies - , even while this underscores the powers of 
the fictional in supplementing the referential and in keeping testimony open as never-ending, un-totalising process.

One step further, the acts of remembrance that fuel the narrative, abortive as they are, might be read in the light of the Freudian concept of Nachträglichkeit, in which not only does the event of the past repeat itself in the present, but also the present revisits the past, thus allowing for a modification and revision of the past (Freud 1964). This has been analysed by Jean Laplanche (171) who shows how, in traumatic cases, a second occurrence makes the first one traumatic, the first acting forward on the second, even while the second modifies the nature and perception of the first, performing chronological crumbling. What Enright performs in The Gathering is a radicalisation of the principle of Nachträglichkeit. She shows that even while the traumatic waves keep shattering the present and affecting the surviving protagonist of this fraught family story, a need for revision, characterising the backward movement of the narrative, is irresistible and assumes pride of place over the forward movement of trauma that respects, overall, the laws of causality. In other terms, the novel reactivates the fictional pole of testimony to pay justice to the backward movement of traumatic time, thus unearthing the basic impulse of testimony: only after a trauma has been activated by a series of at least two violent breakthroughs (possibly occurring in two different generations) is it possible to return to its origins and to be granted the power to perceive it in a different light. One half of Nachträglichkeit informs in its backward movement the whole act of memory that fuels testimony. Now, as the past reference is by definition inaccessible, fiction remains the most relevant idiom of investigation, as it allows for the emergence of anachronism.

\section{Remembrance as event}


Not the least of paradoxes at work throughout the novel is concerned with the way in which acts of remembrance, failed and incomplete as they are, are prolonged by events of remembrance. I am not using the word "event" here in the traditional acceptation brilliantly defined by Andrew Gibson in the wake of Badiou, as based on four main criteria, i.e., rupture, manifestation of the void, creation of fidelities and introduction of innovation (5). What I have in mind is more in the line of Levinas's vision of the ethical relation as predicated on the event of the encounter with the face of the other in which the subject becomes passive and exposed to the other, overwhelmed by and a hostage of alterity. For him, subjectivity is envisaged as dependent on passivity, and alterity becomes an event couched in the passive voice: "exposure as a sensibility is $[\ldots]$ passive $[\ldots]$; it is like an inversion of the conatus of esse, a having been offered without holding back" (75, emphasis added). And perhaps a more specific evocation of what I mean by the passivity that the event confronts the subject with may be found in Derek Attridge's analysis of the singularity of literature and of the literary event as performance, as "a matter both of performing and being performed by the work" (136, emphasis added). In other words, I feel that in The Gathering the testimonial activity is very often seen to edge towards some sort of passivity or vulnerability to the past event that imposes itself on the subject. The welter of the past being repeated in the present thus comes to affect the witnessing subject and gets her to accept her failure, thereby introducing yet another mode of witnessing. This seems to rely on a fundamental rule of testimony that implies "bearing witness to a past that was not witnessed" (Caruth 1996, 151), and this also corresponds to the well-known paradox according to which traumatic memory implies a very precise re-enactment that is, precisely, based on the unknown. Veronica's compulsion to write, to visit the place of the past, to rehearse the same stories endlessly, and her hallucinations seem to point in this direction, making her the receptacle of a knowledge which remains unknown, as if she were the impersonal yet paroxysmal medium of a past that speaks 
out through her without her knowing, which brings to mind, once again, Davoine and Gaudillière's image of "thoughts without a thinker" (157).

One such occurrence is to be found when, after a night spent driving through various sites that used to be childhood haunts, she receives some untimely knowledge, as if in a visitation: "Then, one night, I know the place I am avoiding and, with great and deliberate movements of the wheel, I overcome the car's natural reluctance and drive it all the way to Broadstone." (150). This she does, and finds herself outside a door with the right number, but in a wrong street, the memory event tricking her into yet another memorial cul-de-sac, as if the car were uncannily right and followed the indications of her conscious, rational mind, while her traumatic memories and her unconscious goaded her into yet another blind alley, further away into a narrative of failed possibilities.

And of course, one of the most unmistakable remembrance events is to be associated with the manifestations of the ghost that haunts Veronica's waking dreams. As mentioned above, the narrator evinces most of the symptoms of PTSD: for instance, she hears voices late at night (38), echoes from the past that filter and are uttered into the present. But the most insistent hallucination is visual and is concerned with the ghost that is first objectively described as the product of a visual illusion, i.e., the tilting headrest of the passenger seat in her car (132) that haunts the pages and nights of the narrative till it materialises as fugitive yet tangible presence in Veronica's mother's kitchen on the occasion of the eponymous wake. As she is speaking with her own spectral, fading mother, Veronica feels her husband's protective hand on her back, but when she turns round he is not close to her, and neither is anybody else (138). The uncanny presence of the ghost, which paradoxically fleshes out the presence of the past and of the departed, adds to the general impression of temporal disarray and introduces into the narrative an impossible incarnation (or should I say ex-carnation?) of the past. In other words, the ghost becomes an emblem of the return of the past, hence of remembrance 
not so much as act but as event which comes to affect the traumatised subject, giving her an uncanny knowledge that, fairly literally - and in conformity with the etymology of the adjective-, is compounded of the unknown. Remembrance as event extends the failing powers of remembrance as act and allows an inkling at the truth of the past event even while performing its incomprehensibility.

What the presence of the past also brings to the text is a strong sense of temporal disarray and anachronism as if, under the tyrannical pull of inaccessible traumatic memories, the past were ceaselessly repeated in the present, preventing time from actually flowing. This may be noticed on all pages of a narrative that is written, except for brief moments evoking the reconstitution of a past event, in the present tense, as suggested above. Now, the consistent use of the narrative present throughout a novel is not exceptional. Other contemporary authors have resorted to this type of narration over the last few years: Ian McEwan in Saturday, Jon McGregor in Even the Dogs and Nicholas Royle in Quilt, for instance. Yet, the bulk of fictional production is written in the past tense, and the simple past remains the hallmark of fictional narrative. What I find characteristic of such writing in the present tense is the fact that, without disrupting realistic illusion and without tumbling into experimentation, it introduces some subdued, haunting sense of slight discrepancy into the narrative. For in fact, it is possible to read through the narrative without realising that it is written in the present tense, even while having a sense of difference and displacement. As suggested above, the use of the present tense is instrumental in getting the reader to the thick of things, and by presentifying the past scenes, it makes the presence of the past bleed into the grammatical markers of the narrative. From this point of view, the present tense is the mode of witnessing or testimony, even more so in the case of a trauma narrative in which remembrance is problematical, in which the presence of the past is overwhelming, as if by being too close to the event the narrator could not benefit from the hindsight afforded by retrospect. In the world 
of The Gathering, then, events seem to occur of their own accord, as if they were free of any law of causality and sequence and simply happened and broke into the surface of the narrative irrespective of the narrator's volition. Such a loss of agency, or dispossession, clinches the status of remembrance as event and goes along with the loss of agency characterising the narrator, the loss being an index of her own vulnerability and traumatised state.

Trauma reigns over the narrative and does this with a plurality of cases and characters, even though most of them are related. And quite clearly the traumatic memories that Veronica tries to coax into narrative memory are not so much her brother's as her own, which in itself testifies to her own traumatised state. This is accounted for by the fact that the narrator is not sure that she was herself sexually abused as a child, as indicated above, and she reflects regularly on what is on the minds of men while they are asleep for instance, as is the case of her husband whom she repeatedly contemplates with mixed feelings while he is asleep in the matrimonial bed. Likewise, images of male predation recur throughout the novel, as when Veronica evokes the bus driver (49), the Italian who stalked her along the streets of Venice (51), or else the presence of holes as sites of vulnerability on the bodies of children and women $(76,121,143)$. The crazed temporality of the narrative is one that acts as symptom of the narrator's own trauma. Besides the fragmented narrative and the shredded temporal units, the anachronistic drive contaminates the text, making the present coexist with the past in a radical vision of Nachträglichkeit. This translates every time Veronica finds herself caught in a past that strangely coincides with the present, as when her sister Bear (43) or her sister Kitty (153) appear in front of her in their younger selves, or as when her brother Liam makes the arrow of time fly backwards to evoke some time-travelling episode in reverse:

Because Liam, in his box, is a boy again. He does not fill it more than three-quarters of the way down. The years are drifting away from him. The years are being metabolised, 
until he pees the last of them out, standing by the railings of the Basin in Broadstone, at nine years old. (228)

In all such passages — and in many more-, remembrance is less sought after or triggered off than merely felt and submitted to, anamnesis ceasing to be a voluntary act and becoming an event that affects the witnessing subject.

In such instances, memory is less retrieved that received, and it is essential that such arrival of memory should go along with radical anachronism. The world of The Gathering is one in which temporality is left open thanks to a ubiquitous present, as time is blocked, allowing for anachronism to take place and for periods to pile up, irrespective of any sequence but in accordance with the law of association. This is a way to both thematise and perform the endless present of traumatic states, when the flow of time is suspended (Davoine and Gaudillière 28). The "frozen time" of trauma (Davoine and Gaudillière 167) throws temporality out of joint and makes any memory concomitant with the present of the witnessing, warping causality and making remembrance possible and impossible at the same time.

\section{Conclusion}

In The Gathering, remembrance is perceived as untimely knowledge, hovering between act and event, and between the congealed time of melancholia and the transitional state of mourning. It helps problematise the idea of truth or aletheia, i.e., according to Greek etymology, that which is not forgotten, showing that truth is compounded of what is and what is not forgotten, what is and what is not known. The version of testimony that emerges from the narrative is a vulnerable one in more senses than one. It is vulnerable in that it is open and refuses any attempt at stabilisation or totalisation. But its vulnerability also resides in its 
constant opening to the other's trauma, as clearly indicated throughout a narrative that foregrounds a sense of responsibility for the other's wound: "I owe it to Liam to make it clear-what happened and what did not happen in Broadstone." (223). What the novel teaches us is that no man or woman is an island unto him/herself, and that responsibility for the other goes along with interdependence. One of the messages that Veronica gets through to the reader is that no individual is autonomous, unrelated or independent, whether at the family, the community and the national levels and that, similarly, traumas are not unrelated.

By moving away from a vision of the individual as powerful, fully in charge of him/herself and independent, what Enright suggests is a vision of humanity as interdependent or, at best, mutually autonomous (Held 53). Paying attention to and taking care of the other's trauma is thus a means of developing an aptitude for failure that favours the non-violent relation to the other as ethical relation. By banking on the powers of helplessness and vulnerability as ethical operator, what obtains is a concentration on the essentials of fictional testimony. Seen in this light, The Gathering shows its inspiration as both ethical and political apparatus whose purpose is to make the reader pay attention to various types of social and individual vulnerabilities and invisibilities. At the end of the day, the novel, thanks to the welter of remembrance acts and events, presents the narrator and the reader with a glimmer of hope, with the end of the novel hinting at the possibility of the end of both melancholia and mourning. Remembrance as act and event is thus instrumental in healing and working through.

\section{Works Cited}

Attridge, Derek. The Singularity of Literature. London and New York: Routledge, 2004. Print.

Carlyle, Thomas. Past and Present. 1843. Last accessed at http://www.gutenberg.org/cache/epub/13534/pg13534.html on January 26, 2015. Web. 
Caruth, Cathy, ed. Trauma: Explorations in Memory. Baltimore and London: Johns Hopkins UP, 1995. Print.

Caruth, Cathy. Unclaimed Experience. Trauma, Narrative, and History. Baltimore and London: Johns Hopkins UP, 1996. Print.

Davoine, Françoise et Jean-Max Gaudillière. History Beyond Trauma. Trans. Susan Fairfield. New York: Other Press, 2004. Print.

Dell'Amico, Carol. “Anne Enright's The Gathering: Trauma, Testimony, Memory.” New Hibernia Review 14.3 (autumn 2010): 59-74. Print.

Del Rio Alvaro, Constanza. "Trauma Studies in the Contemporary Irish Novel." In the Wake of the Tiger: Irish Studies in the Twentieth-First Century. Eds. David Clark and Rubén Jarazo Alvarez. Oleiros, La Coruna: NetbibloSL, 2010. 3-16. Print.

Enright, Anne. The Gathering. 2007. London: Vintage, 2008. Print.

Freud, Sigmund. "From the History of an Infantile Neurosis" ("The Wolf-Man"). 1918. The Complete Psychological References of Sigmund Freud vol. XVII. Ed. James Strachey. London: The Hogarth Press, 1964. 7-122. Print.

-. "Beyond the Pleasure Principle." 1920. The Standard Edition of the Complete Psychological Works of Sigmund Freud vol. XVIII. Ed. James Strachey, London: Vintage, 2001. 7-64. Print.

Gardam, Jane. “'Default[ing] to the Oldest Scar': A psychoanalytical Investigation of Subjectivity in Anne Enright's The Gathering." Etudes irlandaises 34.1 (2009): 99-112. Print.

Gibson, Andrew. “'Thankless Earth, but not Entirely': Event and Remainder in Contemporary Fiction." On the Turn. The Ethics of Fiction in Contemporary Narrative in English. Eds. Barbara Arizti and Silvia Martinez Falquina. Newcastle: Cambridge Scholars, 3-19. Print.

Held, Virginia. The Ethics of Care. Personal, Political, and Global. Oxford: Oxford UP, 2006. Print.

Hirsch, Marianne. “Generation of Postmemory.” Poetics Today 29.1 (Spring 2008): 103-28. Print.

Janet, Pierre. "L'amnésie et la dissociation des souvenirs par l'émotion." Journal de psychologie normale et pathologique 5 (September-October 1904): 1-37.

Laplanche, Jean. Problématiques IV. L'après-coup. Paris: PUF, 2006. Print. 
Laub, Dori. "Truth and Testimony: The Process and the Struggle." Trauma: Explorations in Memory. Ed. Cathy Caruth. Baltimore and London: Johns Hopkins UP, 1995. 61-75. Print.

Levinas, Emmanuel. Otherwise than Being, or Beyond Essence. 1978. Doordrecht: Kluwer Academic Publishers, 1991. Print.

McEwan, Ian. Saturday. 2005. London: Vintage, 2006. Print.

McGregor, Jon. Even the Dogs. 2010. London: Bloomsbury, 2011. Print.

Philips, Adam. Trois capacités négatives. Paris: L’Olivier, 2009. Print.

Press, Jacques. La Perle et le grain de sable. Traumatisme et fonctionnement mental. Lausanne : Delachaux and Niestlé, 1999. Print.

Royle, Nicholas. Quilt. Brighton: Myriad, 2010. Print.

Whitehead, Anne. Trauma Fiction. Edinburgh: Edinburgh UP, 2004. Print. 